\title{
Retinol deficiency and Dipetalonema viteae infection in the hamster
}

\author{
D. STÜRCHLER, A. HANCK*, H. WEISER*, U. MANZ* and N. WEISS
}

Swiss Tropical Institute, CH-4051 Basel, and*F. Hoffmann-La Roche \& Co. AG, CH-4001 Basel, Switzerland.

\begin{abstract}
Following chronic retinol (vitamin A) deprivation leading to exhaustion of liver vitamin A reserves below 50 I.U. per liver hamsters were fed diets either deficient in ("Rd": 250 I.U.A $/ \mathrm{kg}$ in experiment I, $1000 \mathrm{I} . \mathrm{U} . \mathrm{A} / \mathrm{kg}$ in experiment II) or enriched with retinol ("Rw": 10000 I.U.A/kg in experiment I and II). After 4 weeks some of the animals (36 in experiment I, 30 in II) were infected with 1503 rd-stage larvae of $D$. viteae, while clean animals were kept as controls. The retinol status, the immune response (indirect fluorescent antibody test: IFAT) and parasitological parameters were examined up to 8 (experiment I) and 12 weeks (experiment II) post infection (p.i.). Rd hamsters had levelling off of weight gain or weight loss, severely deficient retinol levels in serum and liver, and high mortality. Weight gain was less in infected than in uninfected hamsters, and the capacity of infected $R \mathbf{w}$ animals to restore liver retinol was significantly lower than that of uninfected $R w$ animals. IFAT titres were similar in Rd and in Rw animals, but microfilaraemia was significantly enhanced at 8 and $10 \cdot 5$ weeks p.i. in Rd hamsters. While the number of worms recovered from Rd and Rw hamsters was similar, there was a significant increase in the ratio of female to male worms in Rd hamsters. Rd hamsters in experiment I produced 3.3 times the worm mass per $100 \mathrm{~g}$ body-weight than $\mathrm{R} w$ hamsters. Also, the average mass per female worm was significantly higher in $\mathrm{Rd}$ than in $\mathrm{Rw}$ hamsters, and this parameter was negatively correlated with the liver retinol concentration in experiment $I(r=-0.89)$. Retinol deficiency has a marked effect on growth and fertility of $D$. viteae in hamsters.
\end{abstract}

\section{INTRODUCTION}

The parasitological and immunological features of Dipetalonema viteae infection in the golden hamster (Mesocricetus auratus) have been described in detail (WeIss 1970; Mueller 1980; WeISS \& TANNER 1981). After subcutaneous (s.c.) inoculation, thirdstage larvae (L3) moult twice, then develop into fertile males and females within about six weeks. Patency (microfilaraemia) begins shortly thereafter and lasts for 9 to 14 weeks, until microfilaraemia is suppressed by the host's immune response, while adult worms survive in the host (WEISS \& TANNER 1981). Peak microfilaraemia occurs 10 to 13 weeks post inoculation (p.i.).

Interactions of nutrition with immunity and parasitic infections in mammalian hosts are complex (ISLIKER \& SCHUERCH 1981; KEUSCH 1982). In rats, enhancing and depressing effects of protein, pyridoxine, thiamine and retinol deficiencies on infections with filariid worms and immunity have been reported (JAYAPRAGASAM et al. 1977; StOREY 1981, 1982; PraSAD et al. $1980 \mathrm{a}$, b). We were interested in the effects of latent retinol deficiency in man on onchocerciasis and schistosomiasis (STÜRCHLER et al. 1981,1983 ) and were looking for an experimental model for further study. We report on the effects of experimental retinol deficiency in golden hamsters on growth and reproduction of $D$. viteae and on the immune response of the host.

\section{MATERIALS AND METHODS}

Male golden hamsters (M. auratus) of the LAKZ strain were used. They were from a random bred colony from the Institute for Bio-Medical Research Ltd. CH-4414 Fuellinsdorf. They were maintained three per cage and received feed and water ad libitum. 
During breeding they received commercial feed pellets (Naehr- und Futtermittel AG, CH-9202 Gossau, NAFAG product 854 ) containing analytically determined vitamin $A$ and $D_{3}$ concentrations of 3000 and 500 I.U. $/ \mathrm{kg}$, respectively. With this diet the retinol reserves of the colony were slowly reduced over several generations while reproduction of the animals continued.

Four-week-old hamsters were transferred to the experimental laboratories for enforced retinol depletion by feeding retinol-free diet ("A 103", table I) for 7 to 10 days. Hamsters were then separated into two groups, retinol well-fed (Rw) and retinol deficient (Rd) by adding various amounts of retinyl palmitate (ROVIMIX A-500) to the A 103 diet: in Expt I Rd animals received 250 I.U. of retinyl palmitate per kg of feed; in Expt II this was increased to 1000 I.U.A $/ \mathrm{kg}$ because of high mortality of Rd animals in Expt I. Rw animals received 10000 I.U.A/kg in both experiments. For convenience pellets with 10000 I.U.A $/ \mathrm{kg}$ were coloured red with canthaxanthin which lacks provitamin A activity.

Four weeks later animals were s.c. inoculated ("day 0") with 150 L3 of D. viteae. In Expt I $18 \mathrm{Rw}$ and $18 \mathrm{Rd}$ animals were infected, while $12 \mathrm{Rw}$ and $12 \mathrm{Rd}$ animals were kept as clean controls. In Expt II 30 animals were infected (15 each Rw and Rd) and 14 were controls ( 7 each $\mathrm{Rw}$ and $\mathrm{Rd}$ ).

Blood was collected by puncturing the retro-orbital sinus of animals anaesthetized with ether.

Thick drops ( $20 \mu \mathrm{l}$ of blood) were stained with Delafield's haematoxylin and the number of microfilariae $(\mathrm{mff})$ counted in one preparation.

At necroscopy male and female adult worms were removed from the connective tissue, blotted to dryness on filter paper and weighed. The recovery ratio is the proportion of the number of adult worms to the number of larvae inoculated.

The embryogenesis of female worms was determined as follows: batches of five randomly selected females recovered from the same hamster were homogenized in a

Table I. Rodent diet A 103

Composition per $\mathrm{kg}$

A. Casein: extracted, vitamin-free

Rice starch

Coconut oil: heated for $8 \mathrm{~h}$ and aerated

B. Vitamins: $\mathrm{D}_{3}$

2000 I.U.

E

10I.U.

Biotin

$\mathrm{B}_{1}$

$0 \cdot 1 \mathrm{mg}$

$\mathbf{B}_{2}$

$10 \cdot 0 \mathrm{mg}$

$\mathbf{B}_{6}$

$10.0 \mathrm{mg}$

$\mathrm{B}_{12}$

$10.0 \mathrm{mg}$

Ca-D-pantothenate

$40 \cdot 0 \mu \mathrm{g}$

Nicotinic acid amide

$20.0 \mathrm{mg}$

p-Aminobenzoic acid $\quad 70.0 \mathrm{mg}$

Folic acid

meso-Inositol

$1.0 \mathrm{mg}$

$\mathrm{C}$

$30.0 \mathrm{mg}$

Tetrasodium salt of 2-methyl-1,4-naphthohydroquinone $2.0 \mathrm{mg}$ sugar, ad

$10 \cdot 0 \mathrm{~g}$

C. Salts, trace elements

$50 \cdot 0 \mathrm{~g}$ 
glass tissue grinder containing $200 \mu \mathrm{l}$ of normal saline. After gently grinding for $30 \mathrm{sec}$, $800 \mu \mathrm{l}$ of saline was added, the suspension shaken and $10 \mu \mathrm{l}$ examined under a light microscope for $\mathrm{mff}$ and late embryonic stages.

The indirect fluorescent antibody test (IFAT) was used for the determination of antifilarial antibodies in the sera of infected animals (WEISS 1970). Female, adult D. viteae frozen sections were used as antigen. For statistical analysis, the reciprocal titres were log. transformed.

Livers, sections of the dorsal skin and worms were gassed with $\mathrm{N}_{2}$ and, like the sera, kept at $-20^{\circ} \mathrm{C}$ for retinol determination. Sera (approximately $100 \mu \mathrm{l}$ ) were diluted with water to $0.4 \mathrm{ml}$ and with ethanol to $0.8 \mathrm{ml}$ for de-proteination. $0.8 \mathrm{ml} \mathrm{n}$-hexane was added, the solution shaken and centrifuged. The supernatant which contains the hexane-retinol mixture was pipetted and high performance liquid chromatography performed under the following conditions. Stationary phase: Li Chrosorb Si $605 \mu \mathrm{m}$ $25 \mathrm{~cm}$; mobile phase: n-hexane with $2 \%$ isopropanol; detection: UV $325 \mathrm{~nm}$ with Uvikon LCD 725. The peak area was evaluated, compared with an external standard and expressed as I.U.A (1 I.U.A corresponds to $0.33 \mu \mathrm{g}$ retinol).

Retinol was extracted from tissues by saponification at 90 to $95^{\circ} \mathrm{C}$ in a water bath for $20 \mathrm{~min}$ with $30 \mathrm{ml}$ of ethanol and $10 \mathrm{ml}$ of $50 \%$ potassium hydroxide. The saponified solution was cooled, poured into a separating funnel and extracted with $100 \mathrm{ml}$ of ether three times. The extract was washed with water to neutral, dried over sodium sulphate and concentrated to dryness in a rotation evaporator. The residue was dissolved in $\mathrm{n}$ hexane and processed in the same way as the sera.

For statistical evaluation the t-test and the U-test of Wilcoxon, Mann and Whitney were used when indicated.

\section{Growth and mortality}

\section{RESULTS}

Four to eight weeks p.i., Rd animals gained less weight than $\mathrm{Rw}$ animals or lost weight (Fig. 1). The growth curve was more strongly influenced by retinol deficiency than by infection. The only significant difference in mean body weights was observed at week 8 in Expt I between Rw and Rd animals (in the uninfected: t-value $3 \cdot 8, \mathrm{p} \approx 0 \cdot 001$, in the infected: $\mathrm{t}$-value $5.4, \mathrm{p}<0.001$ ). Mortality was elevated in Rd hamsters (in Expt I eight of 30 by 8 weeks p.i., in Expt II six of 22 by 12 weeks p.i.) compared with Rw hamsters (one of 52 at the end of experiments). When Rd animals developed a coarse fur and eyes became covered with a sticky mucous discharge suggestive of clinical retinol deficiency, they usually died within a few days.

\section{Vitamin A status}

Hamsters from another series fed the commercial product (NAFAG 850 with vitamin A) had a median retinol liver concentration of 176 I.U./g (range 139-231, $\mathrm{N}=10$ ).

After feeding a diet in the breeding-station without vitamin A addition followed by a vitamin-A-free experimental diet (A 103) retinol liver reserves of hamsters in this study were exhausted (Table II a). They were somewhat replenished by the 12 th week p.i. in animals on 10000 I.U.A $/ \mathrm{kg}$ with significant differences between infected and uninfected animals in both experiments. However, in all $\mathrm{Rd}$ animals (I and II, uninfected and infected) liver reserves declined to 0 .

Retinol serum concentrations (table II b) reflect the dietary intake: they are adequate in Rw animals, low in animals given 1000 I.U.A/ and virtually undetectable in those receiving 250 I.U.A $/ \mathrm{kg}$. 

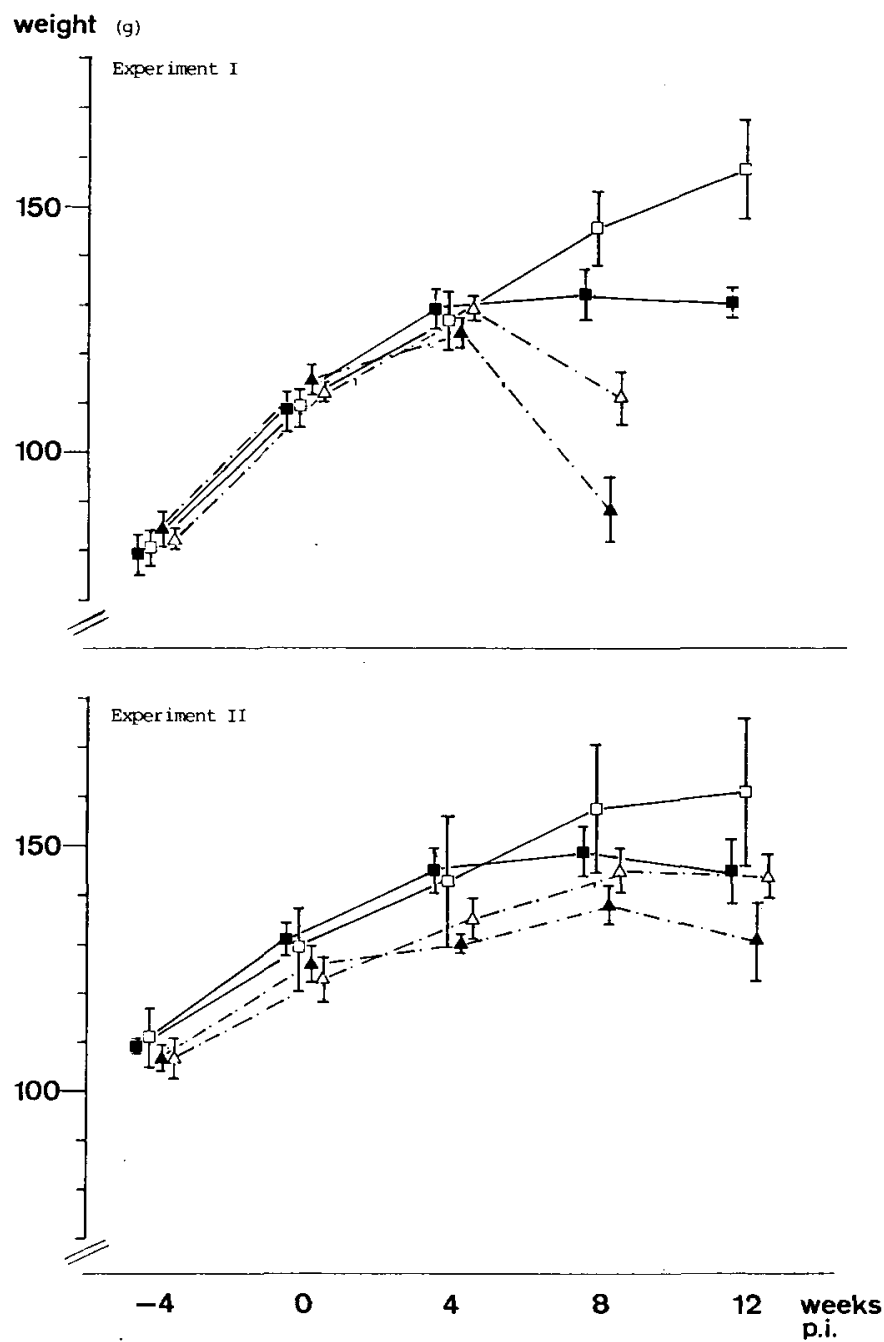

FIG. 1. Weight of hamsters on A 103 diet plus various additions of retinol, before and after infection (p.i.) with 150 L3 D. viteae s.c., and in controls. Well-fed animals (10000 I.U.A/kg diet in Expts I and II): $\square$ infected; $\square$ uninfected. Deficiently fed animals (250 I.U.A $/ \mathrm{kg}$ diet in Expt I, 1000 I.U.A/kg in Expt II): $\Delta$ infected; $\triangle$ uninfected.

Skin retinol concentrations which were determined in Expt I were all $<0.5$ I.U.A per $g(N=43)$ and no difference was found between $R w$ and $R d$ animals and infection status.

\section{Immune response}

IFAT titres in Rd animals were of the same order as in Rw animals (Table III).

\section{Parasitology}

The number of circulating mff was significantly higher in Rd than in Rw animals at 8 and 10.5 weeks p.i. (Table IVa). In Expt II microfilaraemia was looked for already at 5.5 weeks p.i., but it was absent in $R w$ as well as Rd animals, indicating that the release of $\mathrm{mff}$ is not accelerated in Rd animals. 
Table II a. Retinol concentration in the liver of hamsters after retinol-free diet ( -4 weeks p.i.), after addition of retinol to the diet for 4 weeks (week 0 ) and after infection with $D$. viteae

\begin{tabular}{|c|c|c|c|c|c|c|c|c|}
\hline $\begin{array}{c}\text { Weeks } \\
\text { p.i. }\end{array}$ & \multicolumn{4}{|c|}{ Experiment I } & \multicolumn{4}{|c|}{ Experiment II } \\
\hline-4 & \multicolumn{4}{|c|}{$\begin{array}{c}8^{*} \\
(4-22) \\
N=4\end{array}$} & \multicolumn{4}{|c|}{$\begin{array}{c}9 \\
(5-32) \\
N=3\end{array}$} \\
\hline 0 & \multicolumn{2}{|c|}{$\begin{array}{c}10,000 \mathrm{I} . \mathrm{U} . \mathrm{A} / \mathrm{kg} \\
41 \\
(36-50) \\
\mathrm{N}=4\end{array}$} & \multicolumn{2}{|c|}{$\begin{array}{c}250 \text { I.U.A } / \mathrm{kg} \\
2 \\
(1-18) \\
\mathrm{N}=4\end{array}$} & \multicolumn{2}{|c|}{$\begin{array}{c}10,000 \text { I.U.A } / \mathrm{kg} \\
69 \\
(61-77) \\
\mathrm{N}=2\end{array}$} & \multicolumn{2}{|c|}{$\begin{array}{c}1,000 \mathrm{I.U} . / \mathrm{kg} \\
9 \\
(3-15) \\
\mathrm{N}=2\end{array}$} \\
\hline 8 & $\begin{array}{c}\text { inf. } \\
78 \\
(46-127) \\
N=8\end{array}$ & $\begin{array}{c}\text { uninf. } \\
99 \\
(48-129) \\
N=6\end{array}$ & $\begin{array}{c}\text { inf. } \\
0 \\
(0-4) \\
N=10\end{array}$ & $\begin{array}{c}\text { uninf. } \\
0 \\
(0-1) \\
N=7\end{array}$ & inf. & uninf. & inf. & uninf. \\
\hline 12 & $\begin{array}{c}59^{\mathrm{a}} \\
(45-108) \\
N=9\end{array}$ & $\begin{array}{c}109^{a} \\
(81-141) \\
N=6\end{array}$ & & & $\begin{array}{c}75^{\mathrm{b}} \\
(47-132) \\
\mathrm{N}=15\end{array}$ & $\begin{array}{c}111^{\mathrm{b}} \\
(82-123) \\
\mathrm{N}=7\end{array}$ & $\begin{array}{c}0 \\
(0-0 \cdot 3) \\
\mathrm{N}=9\end{array}$ & $\begin{array}{c}0 \\
(0-1) \\
\mathrm{N}=7\end{array}$ \\
\hline
\end{tabular}

* I.U.A per g liver, median (and range); $N$ sample size.

${ }^{a} \mathrm{U}=3, \quad \mathrm{p}<0.005$.

${ }^{\mathrm{b}} \mathrm{U}=17, \quad \mathrm{p}<0.01$.

Table II b. Retinol concentration in the sera of hamsters before (week 0 ) and after infection with D. viteae*

\begin{tabular}{|c|c|c|c|c|c|c|c|c|}
\hline \multirow{2}{*}{$\begin{array}{c}\text { Weeks } \\
\text { p.i. }\end{array}$} & \multicolumn{4}{|c|}{ Experiment I } & \multicolumn{4}{|c|}{ Experiment II } \\
\hline & \multicolumn{2}{|c|}{10,000 I.U.A/kg } & \multicolumn{2}{|c|}{250 I.U.A $/ \mathrm{kg}$} & \multicolumn{2}{|c|}{ 10,000 I.U. $\overline{\mathrm{A} / \mathrm{kg}}$} & \multicolumn{2}{|c|}{1,000 I.U.A $/ \mathrm{kg}$} \\
\hline 0 & $\begin{array}{r}29 \\
1\end{array}$ & $\begin{array}{l}408) \\
4\end{array}$ & & $\begin{array}{l}47) \\
4\end{array}$ & & & & \\
\hline 4 & $\begin{array}{c}\text { inf. } \\
325^{\mathrm{a}} \\
(246-367) \\
\mathrm{N}=7\end{array}$ & $\begin{array}{c}\text { uninf. } \\
401^{2} \\
(352-463) \\
\mathrm{N}=6\end{array}$ & $\begin{array}{c}\text { inf. } \\
13 \\
(0-31) \\
\mathrm{N}=8\end{array}$ & $\begin{array}{c}\text { uninf. } \\
16 \\
(6-40) \\
N=6\end{array}$ & inf. & uninf. & inf. & uninf. \\
\hline 12 & $\begin{array}{c}273 \\
(221-381) \\
N=6\end{array}$ & $\begin{array}{c}305 \\
(187-363) \\
N=6 \\
335 \\
(154-351) \\
N=6\end{array}$ & $\begin{array}{c}0 \\
(0-60) \\
N=9\end{array}$ & $\begin{array}{c}0 \\
(0-47) \\
N=6\end{array}$ & $\begin{array}{c}362 \\
(301-473) \\
N=11 \\
367 \\
(140-407) \\
N=15\end{array}$ & $\begin{array}{c}378 \\
(314-521) \\
N=7 \\
354 \\
(308-429) \\
N=7\end{array}$ & $\begin{array}{c}45 \\
(12-521) \\
N=11 \\
12 \\
(0-101) \\
N=9\end{array}$ & $\begin{array}{c}56 \\
(10-88) \\
N=6 \\
26 \\
(17-60) \\
N=7\end{array}$ \\
\hline
\end{tabular}

*ng per $1000 \mathrm{ml}$, median (and range); $\mathrm{N}$ sample size.

${ }^{\mathrm{a}} \mathrm{U}=1, \mathrm{p}<0.005$.

Table III. Results of the humoral immune response by indirect fluorescent antibody test (IFAT)

\begin{tabular}{|c|c|c|c|}
\hline & 4 weeks p.i. & $\begin{array}{l}\text { procal IFAT } \\
8 \text { weeks p.i. }\end{array}$ & 12 weeks p.i \\
\hline \multicolumn{4}{|l|}{ Experiment I } \\
\hline $\begin{array}{l}\operatorname{Rw}_{w}(\mathrm{~N}=9) \\
\operatorname{Rd}(\mathrm{N}=9)\end{array}$ & $\begin{array}{c}85 \cdot 1 \\
(1.93 \pm 0 \cdot 18) \\
93 \cdot 3 \\
(1.97 \pm 0.26)\end{array}$ & $\begin{array}{c}89 \cdot 1 \\
(1 \cdot 95 \pm 0 \cdot 20) \\
63 \cdot 1 \\
(1 \cdot 80 \pm 0 \cdot 15)\end{array}$ & \\
\hline $\begin{array}{c}\text { Experiment II } \\
\text { Rw }(\mathrm{N}=15) \\
\operatorname{Rd}(\mathrm{N}=9)\end{array}$ & & & $\begin{array}{c}346 \cdot 7^{\mathrm{a}} \\
(2 \cdot 54 \pm 0 \cdot 18) \\
631 \cdot 0^{\mathrm{a}} \\
(2 \cdot 80 \pm 0 \cdot 20)\end{array}$ \\
\hline
\end{tabular}

${ }^{*}$ geometric mean $(10 \mathrm{~g} \overline{\mathrm{x}} \pm \mathrm{SD})$. 
Embryogenesis was only studied in Expt I. At 8 weeks p.i. the geometric mean number of mff and of advanced embryonic stages was $170 / 10 \mu \mathrm{l}$ in $\mathrm{Rw}$ animals and $324 / 10 \mu$ in $R d$ animals $(U=37, p<0.025)$. At 12 weeks p.i. this number was $141 / 10 \mu l$ in $\mathrm{Rw}$ animals.

Results on adult $D$. viteae are shown on Table IVb, Fig. 2 and Fig. 3.

Table IV a. Microfilariae in peripheral blood

\begin{tabular}{|c|c|c|}
\hline & \multicolumn{2}{|c|}{$\begin{array}{l}\text { Number of microfilariae } * / 20 \mu \mathrm{l} \text { blood } \\
8 \text { weeks p.i. } \\
\begin{array}{ll}10.5 \text { weeks p.i. }\end{array}\end{array}$} \\
\hline $\begin{array}{l}\frac{\text { Experiment I }}{\mathrm{Rw}(\mathrm{N}=8)} \\
\operatorname{Rd}(\mathrm{N}=7)\end{array}$ & $\begin{array}{c}20 \cdot 0^{\mathrm{a}} \\
(1 \cdot 30 \pm 0 \cdot 26) \\
416 \cdot 9^{\mathrm{a}} \\
(2 \cdot 62 \pm 0 \cdot 32)\end{array}$ & \\
\hline $\begin{array}{c}\frac{\text { Experiment II }}{\mathrm{Rw}(\mathrm{N}=15)} \\
\mathrm{Rd}(\mathrm{N}=14 \text { at wk. } 8, \\
\mathrm{N}=11 \text { at wk. } 10 \cdot 5)\end{array}$ & $\begin{array}{c}3.9^{\mathrm{b}} \\
(0 \cdot 59 \pm 0 \cdot 15) \\
12 \cdot 8^{\mathrm{b}} \\
(1 \cdot 11 \pm 0 \cdot 11)\end{array}$ & $\begin{array}{c}18 \cdot 8^{\mathrm{c}} \\
(1 \cdot 27 \pm 0 \cdot 20) \\
186 \cdot 0^{\mathrm{c}} \\
(2 \cdot 27 \pm 0 \cdot 11)\end{array}$ \\
\hline $\begin{array}{l}{ }^{\mathrm{a}} \mathbf{U}=5, \quad \mathrm{p}<0.005 \\
{ }^{\mathrm{b}} \mathrm{U}=60, \quad \mathrm{p}<0.05 \\
{ }^{\mathrm{c}} \mathbf{U}=27, \quad \mathrm{p}<0.005 . \\
{ }^{*} \text { geometric mean }(10 \\
\text { To include the num } \\
\text { used which was re }\end{array}$ & $\begin{array}{l}\bar{x} \pm S E) \\
\text { of zero, a log } \\
\text { sed when calc }\end{array}$ & $\begin{array}{l}\text { nsformation was } \\
\text { tilog }(x+1)\end{array}$ \\
\hline
\end{tabular}

Table IV b. Recovery rate and weight of adult $D$. viteae worms from hamsters after 8 (experiment I) and 12 weeks p.i. (experiment II)*

\begin{tabular}{|c|c|c|c|c|c|c|}
\hline \multirow[b]{2}{*}{$\begin{array}{l}\text { Hamsters } \\
\text { Number }\end{array}$} & \multicolumn{3}{|c|}{ Experiment I } & \multicolumn{3}{|c|}{ Experiment II } \\
\hline & $\begin{array}{c}\mathrm{Rw} \\
8\end{array}$ & $\begin{array}{c}\mathrm{Rd} \\
10\end{array}$ & Significance & $\begin{array}{l}\text { Rw } \\
15\end{array}$ & $\begin{array}{c}\text { Rd } \\
9\end{array}$ & Significance \\
\hline \multicolumn{7}{|l|}{ Worms/hamster } \\
\hline $\mathrm{f}$ & $\begin{array}{l}19 \cdot 6 \\
(1 \cdot 6)\end{array}$ & $\begin{array}{l}22 \cdot 5 \\
(2 \cdot 2)\end{array}$ & ns & $\begin{array}{l}19 \cdot 4 \\
(2 \cdot 8)\end{array}$ & $\begin{array}{l}26.8 \\
(3 \cdot 6)\end{array}$ & ns \\
\hline m & $\begin{array}{l}26 \cdot 9 \\
(2 \cdot 5)\end{array}$ & $\begin{array}{l}20 \cdot 7 \\
(2 \cdot 5)\end{array}$ & ns & $\begin{array}{l}26.9 \\
(3 \cdot 2)\end{array}$ & $\begin{array}{l}26 \cdot 0 \\
(4 \cdot 1)\end{array}$ & ns \\
\hline Recovery rate & $\begin{array}{c}0 \cdot 31 \\
(0 \cdot 02)\end{array}$ & $\begin{array}{c}0.29 \\
(0.03)\end{array}$ & ns & $\begin{array}{c}0.30 \\
(0.04)\end{array}$ & $\begin{array}{c}0.35 \\
(0 \cdot 05)\end{array}$ & ns \\
\hline$f: m$ ratio & $\begin{array}{c}0 \cdot 8 \\
(0 \cdot 1)\end{array}$ & $\begin{array}{l}1 \cdot 2 \\
(0 \cdot 1)\end{array}$ & $\begin{array}{c}t=2.9 \\
p<0.01\end{array}$ & $\begin{array}{c}0 \cdot 7 \\
(0 \cdot 1)\end{array}$ & $\begin{array}{l}1 \cdot 1 \\
(0 \cdot 1)\end{array}$ & $\begin{array}{c}t=2.6 \\
p<0.02\end{array}$ \\
\hline \multicolumn{7}{|l|}{$\begin{array}{l}\text { Worm mass } \\
(\mathrm{mg}) / \text { hamster }\end{array}$} \\
\hline $\mathrm{f}$ & $\begin{array}{l}26 \cdot 9 \\
(3 \cdot 0)\end{array}$ & $\begin{array}{c}63 \cdot 7 \\
(13 \cdot 7)\end{array}$ & $\begin{array}{c}\mathrm{t}=2.6 \\
\mathrm{p}<0.02\end{array}$ & $\begin{array}{l}34 \cdot 8 \\
(6 \cdot 3)\end{array}$ & $\begin{array}{l}61 \cdot 9 \\
(9 \cdot 6)\end{array}$ & $\begin{array}{c}t=2.4 \\
p<0.05\end{array}$ \\
\hline $\mathrm{m}$ & $\begin{array}{l}14.0 \\
(1.9)\end{array}$ & $\begin{array}{l}17.9 \\
(3.7)\end{array}$ & ns & $\begin{array}{l}15 \cdot 4 \\
(2 \cdot 1)\end{array}$ & $\begin{array}{r}17 \cdot 5 \\
3 \cdot 2\end{array}$ & ns \\
\hline $\mathrm{f}+\mathrm{m} / 100 \mathrm{~g}$ hamster & $\begin{array}{l}30 \cdot 8 \\
(3 \cdot 2)\end{array}$ & $\begin{array}{l}101 \cdot 9 \\
(24 \cdot 1)\end{array}$ & $\begin{array}{c}t=2.9 \\
p<0.01\end{array}$ & $\begin{array}{l}36 \cdot 7 \\
(7 \cdot 1)\end{array}$ & $\begin{array}{c}62 \cdot 7 \\
(10 \cdot 5)\end{array}$ & $\begin{array}{c}t=2.1 \\
p<0.05\end{array}$ \\
\hline $\mathrm{f}: \mathrm{m}$ weight ratio & $\begin{array}{l}2 \cdot 1 \\
(0 \cdot 3)\end{array}$ & $\begin{array}{c}3.9 \\
(1.0)\end{array}$ & $\mathrm{ns}$ & $\begin{array}{c}2 \cdot 2 \\
(0 \cdot 2)\end{array}$ & $\begin{array}{c}4 \cdot 1 \\
(0 \cdot 6)\end{array}$ & $\begin{aligned} t & =1.9 \\
p & <0.01\end{aligned}$ \\
\hline
\end{tabular}

* mean (SE)

$\mathrm{f}=$ female, $\mathrm{m}=$ male, $\mathrm{ns}=$ not significant. 
mg D.v. / 100g

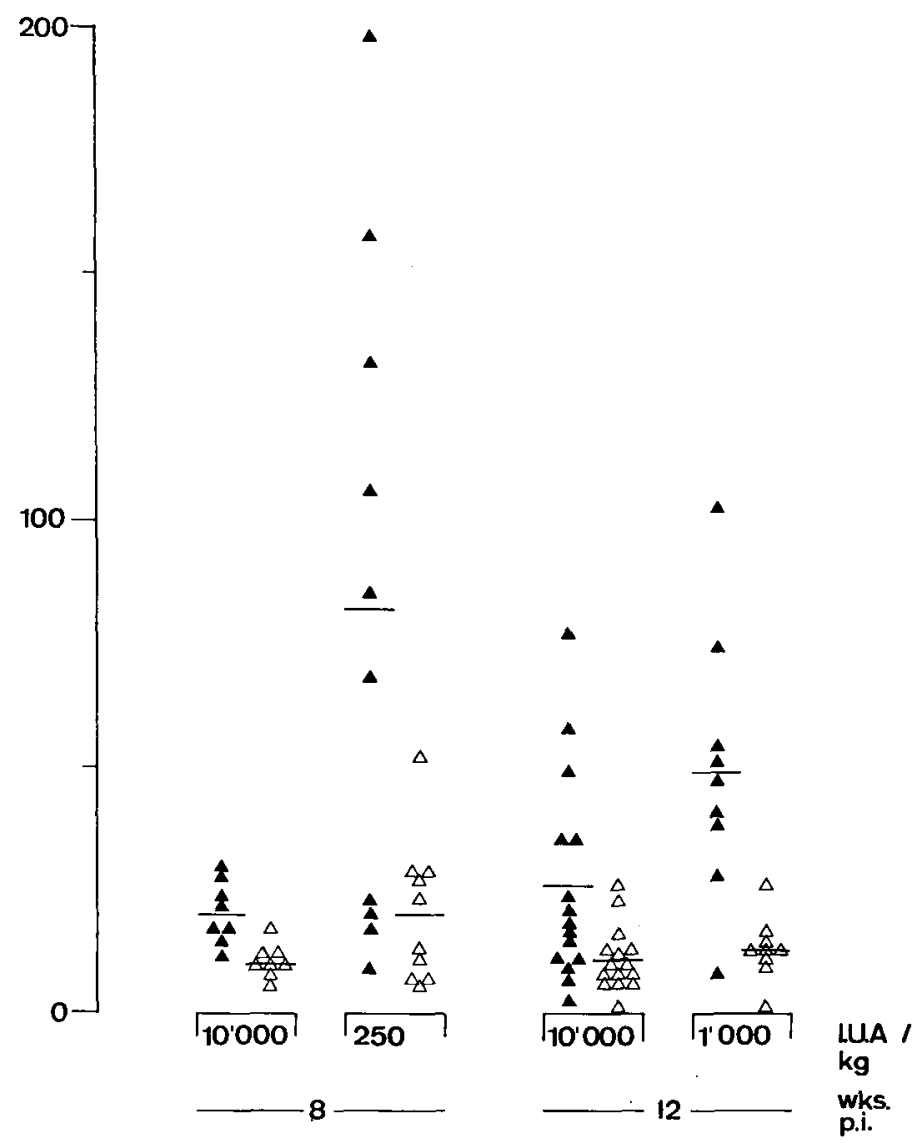

FIG. 2. Mean weight of female and male worms recovered, standardized to a hamster body-weight of $100 \mathrm{~g}$. Data at week 8 are from Expt I, those at week 12 from Expt II. Bars indicate group means. $\Delta$ females; $\triangle$ males.

The recovery ratio was similar in all groups. However, more females were recovered from Rd than from Rw animals, and the female : male ratio was greater than one in both experiments. Rd animals produced large worm masses. Standardized to a body-weight of $100 \mathrm{~g}$, hamsters on 250 I.U.A $/ \mathrm{kg}$ produced a 3.3 times higher worm mass than the corresponding $\mathrm{Rw}$ hamsters. This increment in worm mass is attributable to both an increase in the number of female worms in Rd hamsters (male worms are lighter than female worms weighing 0.5 to $0.8 \mathrm{mg}$ on an average), and to an increase in mass per female worm; the average weight (S.E.) of females at 8 weeks p.i. in Expt $I$ is $2.5 \mathrm{mg}(0.4)$ in $\mathrm{Rd}$ hamsters and $1.4 \mathrm{mg}(0 \cdot 1)$ in $\mathrm{Rw}$ hamsters (t-value $2 \cdot 6, \mathrm{p}<0 \cdot 02)$. Corresponding data of Expt II at 12 weeks p.i. are $2 \cdot 3(0.2)$ and $1.7(0.1) \mathrm{mg}$ (t-value $3 \cdot 3, \mathrm{p}<0.01$ ).

Retinol liver concentrations were negatively correlated with the mean weight per female worm in Expt $I$ only (at 8 weeks p.i. $r=-0.77, p<0.05$, at 12 weeks p.i. $r=$ $-0.89, \mathrm{p}<0.01$ ). Females weighing over $2.5 \mathrm{mg}$ were recovered only from hamsters with retinol concentrations below 1 I.U./g liver and $25 \mathrm{ng} / 1$ serum, respectively.

In Expt II the retinol concentration per adult $D$. viteae were determined in four worm batches each from $\mathrm{Rd}$ and $\mathrm{Rw}$ hamsters respectively; parenchymal retinol concentration was near to zero in all animals. 
mean weight / D.v.

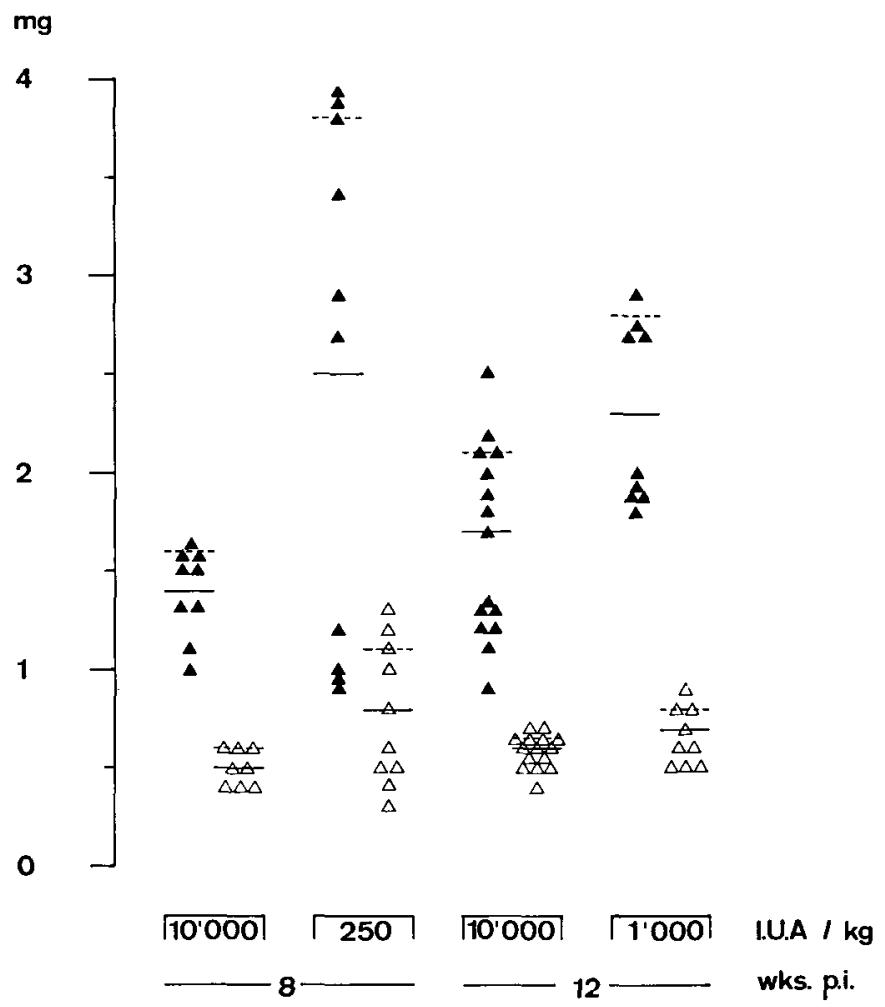

FIG. 3. Mean weight of adult worms recovered per hamster. Data at week 8 are from Expt I, those at week 12 from Expt II. Bars indicate group means, interrupted lines give the standard error (to one side only). $\Delta$ females; $\triangle$ males.

\section{DISCUSSION}

This study demonstrates a strong effect of retinol on the physical condition of hamsters and on growth and reproduction of $D$. viteae worms. It also shows that the host's humoral immune response remains unimpaired during retinol deficiency (even at week 12 p.i. titres were significantly higher in deficient animals), and that the parasite is detrimental to both the growth and the retinol liver reserves of the host but otherwise less harmful than the retinol deficiency.

While this study was in progress STOREY (1982) reported on retinol deficiency in cotton-rats infected with $L$. carinii. Like us, he found better growth of retinol well-fed rats $(\mathrm{Rw})$ than of ill-fed rats $(\mathrm{Rd})$, a more marked influence of retinol than of infection on growth of the rats, longer worms in Rd than in Rw rats, and serum retinol concentrations in proportion to the diet but uninfluenced by infection. However, Storey found an increased recovery rate in Rd rats, and retarded larval development in female worms recovered from them. Possible explanations for this variance are: (i) the type of retinol depletion, maintenance diet and parasitological parameters used are different in the two studies; (ii) it may be more difficult to recover $D$. viteae from the connective tissue of hamsters than $L$. carinii from the pleural cavity of cotton-rats, although in the former model it is easier to quantify the infective dose than in the latter. (iii) the metabolism of retinol in $L$. carinii is different from that in D. viteae. We regard this explanation as the most probable. In sharp contrast to $D$. viteae we have found a 
median retinol concentration of $12.6 \mathrm{I} . \mathrm{U} . / \mathrm{g}$ in adult Onchocerca volvulus from man (STÜRCHLER et al., 1981). In adult female and male D. viteae and in microfilariae all obtained from hamsters on commercial diet (NAFAG 850) we have found retinol concentrations of $0.18,0.20$ and 0.01 I.U./g respectively (D. Stürchler, M. Tanner and A. Hanck, unpublished), indicating that the retinol demands of a parasite species may vary with the diet the host is receiving.

It might be argued that inanition and hence protein-calorie malnutrition contributed to the differences between $\mathrm{Rw}$ and $\mathrm{Rd}$ animals observed in our study. This is not likely, however, since opposite effects are observed in experimentally protein deficient rats which are infected with $L$. carinii, that is a prolonged prepatency, depressed parasitaemia and decreased worm length (JAYAPRAGASAM et al. 1977; STOREY 1981).

While some nutritional effects on parasites may be mediated by the altered immune response of the host (ISLIKER \& SCHUERCH 1981), others are not, as has been shown by PRASAD et al. $(1980 \mathrm{~b})$ in pyridoxine deficient rats that were refractory to experimental $L$. carinii infection, although their humoral immune response seemed depressed. In our experiments the retinol effects seem unlikely to be mediated through an altered immune response which was of the expected quality also in $R d$ animals. How then do adult $D$. viteae females prosper so well in retinol deficient hamsters? A causal relationship is suggested (i) by the negative correlation between retinol liver concentration and average female worm weight in severely depleted hamsters, (ii) by the slower restoration of liver reserves in infected than in uninfected hamsters, (iii) by the fact that bulky female worms grow in retinol-exhausted hosts. Is an adequate host tissue retinol concentration inhibitory of growth and reproduction of female $D$. viteae? Studies on the metabolism of Brugia pahangi indicate that this filariid takes up and incorporates retinol, metabolizing it to substances which may be involved in filarial glycoprotein synthesis (COMLEY \& JAFFE 1983).

\section{REFERENCES}

COMLEY, J. G. W. \& JAFFE, J. J. (1983) Retinol and filarial glycoprotein synthesis. Transactions of the Royal Society of Tropical Medicine and Hygiene, 77, 136.

ISLIKER, H. \& SCHUERCH, B. (editors) (1981) The impact of malnutrition on immune defence in parasitic infestation. H. Huber Publishers: Bern, Switzerland, 1-199.

JAYAPRAGASAM, M., BAGAI, R. C. \& SUBRAHMANYAM, D. (1977) The effect of malnutrition on filarial infection in albino rats. Indian Journal of Medical Research, 65, 346-352.

KEUSCH, G. T. (editor) (1982) The biology of parasitic infection. Workshop on interactions of nutrition and parasitic diseases. Reviews of Infectious Diseases, 4, 735-911.

MUELLER, H. A. (1980) Zur Dynamik und Beeinflussbarkeit der Mikrofilaraemie und des "therapeutischen Schocks" bei der Dipetalonema viteae-Infektion der Mastomys natalensis. Giessen: Diss. Institut für Parasitologie der Justus-Liebig-Universität.

PRASAD, R., RAO, Y. V. B. G., MEHTA, K. \& SUBRAHMANYAM, D. (1980a) Effect of thiamine deficiency on the filarial infection of albino rats with Litomosoides carinii. International Journal for Parasitology, 10, 93-96.

PRASAD, R., RAO, Y. V. B. G., SINDHU, R. H. \& SUBRAHMANYAM, D. (1980 b) Effect of pyridoxine deficiency on Litomosoides carinii infection in albino rats. Transactions of the Royal Society of Tropical Medicine and Hygiene, 74, 459-462.

STOREY, D. M. (1981) Malnutrition and experimental filariasis. Parasitology, 82, 35-36.

STOREY, D. M. (1982) Vitamin A deficiency and the development of Litomosoides carinii (Nematoda, Filarioidea) in cotton rats. Zeitschrift für Parasitenkunde, 67, 309-315.

STÜRCHLER, D., HOLZER, B., HANCK, A. \& DEGREMONT, A. (1983) The influence of schistosomiasis on the serum concentrations of retinal and retinol binding protein of a rural population in Liberia. Acta Tropica, 40, 261-269.

STÜRCHLER, D., WYSS, F. \& HANCK, A. (1981) Retinol, onchocerciasis and Onchocerca volvulus. Transactions of the Royal Society of Tropical Medicine and Hygiene, 75, 617-618. 
WEISS, N. \& TANNER, M. (1981) Experimental filariasis in the Syrian hamster; immunological aspects of complex host-parasite interactions. In: Streilein, J. W., Hart, D.A., Stein-Streilein, J., Duncan, W. R. and Billingham, R. E. Hamster immune responses in infectious and oncologic diseases. Plenum Press: New York, 253-265.

WEISS, N. (1970) Parasitologische und immunbiologische Untersuchungen ueber die durch Dipetalonema viteae erzeugte Nagetierfilariose. Acta Tropica, 27, 219-259.

Accepted 18th July, 1984. 